\title{
Issues Surrounding Government Support for Social Entrepreneurship as a Change Agent
}

\author{
Faudziah Zainal Abidin
}

Islamic Business School, College of Business

06010 UUM Sintok, Universiti Utara Malaysia

Email: faud@uum.edu.my

\section{Emmanuel John Kaka}

School of Economics, Finance and Banking, College of Business

06010 UUM Sintok, Universiti Utara Malaysia

Email: youngkaka2002@yahoo.co.uk

DOI: $\quad$ 10.6007/IJARBSS/v4-i9/1148 URL: http://dx.doi.org/10.6007/IJARBSS/v4-i9/1148

\begin{abstract}
The main aim of this paper is to determine the issues surrounding how government support for social entrepreneurship might possibly influence the social impact on our communities and the growth and development of our economy as a whole. The study uses mainly documentary source to generate the data for this study. The paper also found out that the government is contributing in assisting the social entrepreneurs to identify where to get more resources to finance their activities, organizing enlightenment campaign to create awareness to the citizens in the communities concerning social problems, coordinate and implement programs in conjunction with other organization. Despite the effort of government in this direction, there are some little issues that have hindered the success of government support for social entrepreneurs, such as initiating programs which are not in accordance to government priority areas, issues of power sharing between the government and social entrepreneurs.
\end{abstract}

Keywords: Government support, Social entrepreneur, Commercial entrepreneur, Social impact, Communities.

\section{Introduction}

Social entrepreneur is a respected business venture that can offer services to all kinds or classes of people in the community. It is all about assisting the poor to gain promotion in their businesses, socially, morally and economically to get them out of poverty (George, 2009). Social entrepreneur is a medium through which social value is created, in which resources are combined or brought together in a new or different form to meet social needs, create new organization to stimulate and encourage social change (Moss et al. 2008). It offers the multinational corporation managers the chance to acquire knowledge, make effort to collaborate with others in the interest of the corporation, in order to create social value to those in need or the poor people (Seelos \& Mair, 2005). Social entrepreneur helps in making 
the poor to become useful resource in the organization. This in turn change and improve their situation for the better, through the creation of human capital (education, health), social capital (changing their ways of life and behaviors) (Seelos \& Mair, 2013).

Jain (2009) opined that the activities of social entrepreneurs do have a significant influence on people's life all over the world. For example, Muhammed Yunus pioneering work of Grameen Bank in Bangladesh is currently used in more than 58 countries around the globe. Therefore, social entrepreneur can be seen as God gifts to individuals and the community at large. This is because in undertaking the task of running the business enterprise, they sometimes give away part of their wealth, to take care of the poor individuals or the community at large. Hence, their impact is felt or noticed in the communities they are operating (Yusuf, Ibrahim \& Hamid, 2013). Nowadays, social works had become silence on the topic of social entrepreneurs, sources made available have shown that few schools of social works give training on social entrepreneurship and a very small number of social workers are putting pen on the social entrepreneurship (Ventresca \& Dorado, 2013). That notwithstanding, Social entrepreneurs are to be regarded as normal every day person who left the quest for chasing private wealth in order to create social values (Dees, 1998), and serve as a building block for the enhancement and development of the community (Jain, 2009). The social enterprise model works very well like the traditional business ventures. In addition, a social enterprise provides important changes in the society because it is used as a means to proffer solution to social problems and hence, they need government support.

Some government has started supporting social entrepreneurship by creating new organizations to encourage the establishment of new social entrepreneurial ideas. In addition, they provide financial support to encourage and promote these ideas or initiatives. Presently, many social entrepreneurship centres have been established and many conferences and special issue journals have increased in recent time to encourage the establishment and promotion of social entrepreneurship to solve social problems (Choi, \& Majumdar, 2013). Even though, social entrepreneurship cannot be the solution for all social problems or vies on earth (Marques, 2008). The program has the ability to resolve some of the social problems in our communities and the world in general. Hence, there is the need to make people understand its importance and be encouraged to take part or rather support social entrepreneurship and be supported as well (Simha \& Carey, 2012). That is the reason for some years now; many successful business entrepreneurs have devoted most of their income to support social entrepreneurship. For example, Jeff Bezor pioneer of the Amazon, not quite long ago gave out a sum of 1 million dollars as a price for innovative approaches and breakthrough solutions to the effective enhancement of the societies and the nation in general. Jeff Skoll, co-founder of eBay, established a foundation and donates funds of 4.4 million pounds to create a centre for research on social entrepreneurship (Daru \& Gaur, 2013). But, the extent of government support and the legislative environment provided is yet to be known with degree of certainty (Koresec \& Berman, 2006).

To be a successful social entrepreneur to bring about important and relevant changes is a welcome idea, but the entrepreneurs most stick to the qualities found in social enterprises. The main objective of this study is to determine the issues surrounding government support for social entrepreneurship and how it affects the social impact on our communities and the growth and development of our economy as a whole. The paper is made up of introduction, 
concept of social entrepreneur and social entrepreneurship, difference between social entrepreneur and commercial entrepreneur, some well known social entrepreneurs, government support for social entrepreneurs, issues surrounding or concerning government support and the conclusion.

\section{Literature Review}

This section looks at the definition of the social entrepreneur and social entrepreneurship, difference between social entrepreneur and commercial entrepreneur, social entrepreneur as a change agent, government support for social entrepreneurship, issues against government support and some well know social entrepreneurs.

\subsection{Concepts of the Social Entrepreneur and Social Entrepreneurship}

There is no consensus as to what social entrepreneur and social entrepreneurship are and what they are not (Hoogendoorn, et al. 2008). The concepts are surrounded with a lot of controversies (Dacin, Dacin \& Matear, 2010). Therefore, enough understanding and description of social entrepreneurship does not exist at the moment due to the fact that social entrepreneurship has different element of both profit and nonprofit making organization (Thompson, 2000; Roper \& Cheney, 2005) that is why there are a lot of debate going on presently as to what social entrepreneur and social entrepreneurship is among academia and practitioners (Thompson, 2008; Robinson, 2009; Mair \& Mart, 2009; Yusuf, Ibrahim \& Abdulhamid, 2013). The definition seems to possess various or many versions as a result of geographical location, academic backgrounds and the extent of the country's economic development (Kerlin, 2009). Social entrepreneurs is seen to be the quickest growing figure or number of organizations that provide services to the poor by meeting their basic necessities of life in a place or situation where well established and existing institutions and market were unable to satisfy or filled (Seelos \& Mair, 2005). Nandan, (2013) concluded that social entrepreneurship has re-emerged in the literature due to the trend of events happening in our societies, such as increase privatization of government run programs, reduction in government revenue due to current and past recessions, increase reliance on soft money to fund or supplement budget and also the strong critics in the current social welfare system going on. Therefore, social entrepreneur is also seen as a process of building and changing or transforming institutions, by creating and designing programs for solving social problems of the citizens of the citizens themselves; such as illiteracy, sickness and diseases, human right abused corruptions, environmental degradation and poverty in the society, so as to make life to be better for many to live (Horgan, 2013).

Social entrepreneurs are persons with fresh or new ideas to solve problems, who are working tirelessly in the promotion of their visions; they are people who do not have no as a solution and who will not surrender until they are able to make their ideas known to people or communities as far as possible (Daru \& Gaur, 2013). An individual, organization, group, network or merger of organizations that are looking for sustainability, large scale change through an innovative idea created from what nonprofits, governments, and business organizations do to solve important social problems in the society is refer to social entrepreneur (Light, 2006). Daru and Gaur (2013) observed that social entrepreneurs are persons who identifies areas where there is needs to meet some unmet needs that the welfare system of the state are unable or 
cannot be able to provide, by bringing together the resources like money, people (volunteers), land and premises to utilize them in order to make a difference.

The definition of social entrepreneur focuses on individual and organizations that initiate and developed fresh services, programs and answers to particular social problems; for example, unwanted pregnancy, poor consumer credit, illiteracy and or those that meet the needs of special types of people like; immigrant population, veterances, children with disabilities, people with medical problems (Korosec \& Berman, 2006). Therefore, for a person to become an effective entrepreneur, that person most have the capability to peruse opportunities, possess a genuine and a focus commitment to the community that will last for a long time (Brooks, 2002).

\subsection{Differences between Social Entrepreneur and Commercial Entrepreneur}

Literatures have shown that there is no one best or precise definition of entrepreneurship (Davidson, 2004). Adding social to the name entrepreneurship increases the difficulty in having a common understanding of the word. Despite the controversies, Austin, et al. (2006) and Kato and Mushi (2012) gave about four distinctions between commercial entrepreneurship and social entrepreneurship. These are:

They vary in the nature and type of opportunities they explore. Social entrepreneurship is more concern with perusal and exploring those opportunities which commercial entrepreneurship are unable to do or provide. This is because social entrepreneurs have nothing to do with maximization of profit apart from maximization of social value to make available the provision of education, water, shelter, health services, food, and financial support for the people in the communities (Domenico, Haugh, \& Tracy, 2010: Muller, 2012).

Social entrepreneurs have passion for social mission and so take most of their time trying to maximize social value (Dees, 1998). The main purpose of social entrepreneurs is to give people in the community social value not to make profit. The return, a social entrepreneur received is the social value creation for the people. This is totally at variance with the commercial entrepreneur's mission.

The performance measurement of social entrepreneurship is difficult due to the nature of activities and mission they are professing. Certo and Miller (2008) observed that the standard for social entrepreneur performance measures are less and more idiosyncratic to a given environment and organization. Therefore, is hard to measure social change taking place in the community. The difficulty in measuring social change is as a result of temporal dimension, non quantifiability, perceptive differences and multi-causality of the social impact that has been created in the society.

Social and commercial entrepreneurship varies in the way and manner they mobilized resources (Certo \& Miller, 2008). Commercial entrepreneurs can collect loan from financial institutions and employ workers immediately they proposed to start a business, but social entrepreneurs have to mobilize human and financial resources before creating and starting the business venture. The nature or type of mission social entrepreneur is carrying makes it hard to get resources easily to start the business venture. To begin a new social venture the social entrepreneur needs to know where and how to get the sources of funding. This can only come from those who have interest on social value creation (Certo \& Miller, 2008). Those with human capital that are willing to do the job in the social business.Social entrepreneurs depend on volunteers to serve in a strategic position like members of the board of directors, who can also 
assist in raising funds and gives professional services in the organization (Austin et al. 2006). There is no doubt that social entrepreneurs need support from donors, institutions, friends and family and other firms. Miller and Wesley (2010) opined that social entrepreneurs must establish strong networks that will give room to funding, management staff, and board members to bring change for the mission to gain support.

\subsection{Social Entrepreneur as a Change Agent}

Social entrepreneurs can be seen to perform the vital role of change agents in the social sector of the communities. The following are some of the ways a social entrepreneur can serve as a change agent according to (Daru and Gaur, 2013):

- Acting with confidence without being constraint of resources at hand at the moment.

- Taking part always in the process of innovation, learning and adaptation.

- Adopting and carrying on a mission to establish and maintain social value to the community for unforeseeable future not private value.

- Showing a high sense or degree of responsibility and accountability to the communities served for the results created.

- Identifying new opportunities and tirelessly pursuing them to serve the social mission being undertaken in the communities.

Therefore, social entrepreneurs are an individual who identifies areas where there are opportunities to fulfill or satisfy some needs that cannot be provided by the welfare system, who brought together the resources and uses them to make a difference in the community. The resources are money, land and premises, volunteers and the people in order to create a change in our society.

\subsection{The Government Support for Social Entrepreneurship}

Governments at all levels are expected to give maximum support to social entrepreneurs, because of the following reasons: social entrepreneurs come into communities with the resources and leadership to communities that need their services to address some of their pressing problems. Secondly, nonprofit making organizations are being regarded as cost effective service providers (Koresec \& Barman, 2006; Savas, 1987). Thirdly, social entrepreneur gives the government the opportunity to concentrate and pay their attention and energies to other areas that private individuals and organization cannot be able to handle such as security, environmental regulation (Fredrickson, 1982; Kuratko \& Hodgetts, 1998). Koresec and Berman, (2006) suggests that government should explore the following channels to support the effort of social entrepreneurs in their bid to initiate and carry out new programs in the community to solve social problems:

Acquisition of resources: government can help social entrepreneurs acquire resources through the provision of public funds and by assisting them to get more from other organization (e.g government can direct social entrepreneurs to go and collect grant from writers who can help them to identifies funding sources and grant opportunities. The community can give start up or beginning capital for the development of the program (Herman \& Redina, 2001). In addition, government can give access and referrals to others to assist social entrepreneurs to get resources, including groups, association connected to leasing in the society. 
Creating awareness: government is expected to support and encourage social entrepreneurship by continuously increasing awareness to the people on the activities and missions of the social entrepreneurs in their communities (Lewis, 1980; Young, 1997). Government can request elected politicians to discuss issues concerning the social entrepreneurship in their public gathering (Lewis, 1980). The government is expected to also make available to the social entrepreneur's data on social issues in their communities and enlighten them on how to sources grants to use in attaining their social missions (Koresec \& Berman, 2006).

Coordination and implementation: it is a known fact that most initiatives emanating from the community needs proper coordination and implementation to achieve its objectives.Since government has the requisite expertise in forming and administering networks and coalition of organizations (Berman, 1996), government should decide to work with anoother organization to make sure that adequate or enough cooperation and information beneficial to each other is shared and kept. This can be done by assisting social entrepreneurs on issues that makes coordination, implementation of programs easier and simple. Most especially, when it has to do with the speed of approval or permission to carry out some projects (Koresec, \& Berman, 2006). More so, the government can help in establishing and leading the development of the coalition (Luke, 1998). This is because the joining together of plenty activities can lead to a great social impact on the social entrepreneurship capability and the people in the community, unlike when it has to be a single activity (Thompson, 2002).

\subsection{Issues against Government Support}

There are some issues or concern that can cause a reduction for government support for social entrepreneurships. These are according to Koresec and Berman, (2006):

Social entrepreneurship is about power sharing, as such some elected officials and public managers may be nonchalant or not be willing to give up the exercise of control over their issues in the community.

Social entrepreneurs differ in their capabilities and the ways and manners they administer programs professionally, therefore some of their strategies will contribute in making government official uncomfortable.

Social entrepreneurs may initiate programs which are not in accordance with the government existing programs, priority for funding, or policies like programs that are in conflict with the public programs which are already in existence.

Contractual and legal consideration may hinder some kind of support or funding for the social entrepreneurs.

Government support may also corrupt the social mission of nonprofit making by giving attention only to areas of revenue generation opportunities and funding.

However, even though other programs have indicated that they can also work toward achieving their mission as well as be entrepreneurial (Brown \& Troutt, 2004). Government officials may not agreed that some strategies or causes are right or appropriate for public support. Since everybody may have his favourite charity, together with the elected official and senior managers who are requested to sit on the governing boards of nonprofit organization. Therefore the issues of whose program receipt funds and who does not can only be determined by an individual experience or background with many groups. 
Therefore, it is pertinent to note that information concerning government support for social entrepreneurs and their impact are lacking. Public managers' views suggest that social entrepreneurship is seen everywhere in the communities and is significantly enhance by government support.

\subsection{Some Well Known Social Entrepreneurs}

The Grameen Bank (GB)

Muhammad Yunus was the founder of Grameen Bank in Bangladesh in 1976. Yunus believes that poor people, mostly landless women can be trusted with a loan or credit most especially when they are organized in mutually accountable groups. This philosophy works because there was a very high repayment rate from the poor borrowers. Therefore, small group of five where form by the Grameen Bank to provide bonding to serve as a collateral. Those who have taken part in the program in the past have shown that they can be reliable borrower and real entrepreneurs, as such; they have uplifted their status in their communities socially. This singular moment was started by Yunus, who have created over $90 \%$ of the millions of women microcredit borrows all over the world today.

The Self- Employed Women Association (SEWA)

The organization was established in 1972 by Ela Bhatt as a trade union whose initial programs gave attention to the enhancement of the members working conditions, by influencing the actions of policy makers and the local police to their advantage. The union is made up of women who earned their living in the following occupation that have been difficult to organized historically; manual laborers, service providers, hawkers, vendors and home-based producers. Later the union provides some varieties of services that their members do not partake in. SEWA as the first and biggest trade union of the informal sector has about 315,000 members approximately. Apart from its trade union activities the organization has other institutions such as a bank that gives financial resources to their members, a school that gives training and research, and a housing trust for its members. This association has grown to become an international force and labor moment in the whole universe.

The Green Belt Movement (GBM)

The Wangari Maathai and the national council of women in Kenya founded GBM in 1977. The green belt movement organizes small groups of poor individuals in the communities in the urban and rural areas to plant, grow and care for the trees in green belts on private and public land. The GBM was able to organize almost over 6,000 groups in both urban and rural areas and has planted more than 20 million trees in Kenya. The movement was able to organize the groups in the communities to go for self-determination, to enhance their livelihood and preserve their environment and pursue their quest for social and political justice. GBM has taken this campaign internally by forming "African network" to help green consciousness and social justice groups in some countries in Africa.

\section{Conclusion}

The study is of the view that it is difficult for the social entrepreneurs to come knocking at the government door, if the government did not create a conducive atmosphere for them to take advantage in the environment. That is to say governments must to be willing to open the door 
in the first instance, for the social entrepreneurs to feel free to approach the government. In addition, the two most have regard for each other as important partners for the progress and development of the communities. If the government refused to give them a conducive environment to operate they may leave to another environment or communities.

The paper found out that the government is contributing in assisting the social entrepreneurs to identify where to get more resources to finance their activities, organizing enlightenment campaign to create awareness to the citizens in the communities concerning social problems, coordinate and implement programs in conjunction with other organization. But the extent to which government support the social entrepreneur is not known. Lastly, despite the effort of government in this direction, there are some little issues that have hindered the success of government support for social entrepreneurs, such as initiating programs which are not in accordance to government priority areas, issues of power sharing between the government and social entrepreneurs.

\section{References}

Austin, J., Stevenson, H. \& Wei-skillen, J. (2006). Social and commercial entrepreneurship: same, different or both? Entrepreneurship Theory and Practice, 30(1), 1-22.

Berman, E. (1996). Local government and communities based strategies: evidence from a national survey of social problem. American Review of Public Administration, 26(1), 7191.

Bornstein, D. (2004). How to change the world: social entrepreneurs and power of new ideas. Oxford University Press, New York.

Brooks, A. (2002). Can nonprofit management help answer public managements "big questions".

Public Administration Review, 62(3), 259-260.

Choi, N. \& Majumdar, S. (2013). Social entrepreneurship as an essential contested concept: opening a new avenue for systematic research. Journal of Business Venturing, 1-14.

Certo, S.T. \& Miller, T. (2008). Social entrepreneurship: key issues and concepts. Business Horizon, 51(4), 267-271.

Dacin, P.A., Dacin, M.T. \& Malear, M. (2010). Social entrepreneurship: why we don't want a new theory and how we move forward from here. The Academy of Management Perspectives, 24(3), 43-54.

Daru, M.U. \& Gaur, A. (2013).Social entrepreneurship a way to bring social change. International Journal of Business and Management, 2(1), 26-29.

Davidson P. (2004). Researching entrepreneurship. Boston, M.A: Springer.

Dees, J.G. (1998). Enterprising non profits. Harvard Business Review, Jan-Feb. 55-67.

Dees, J.G. (1998). The meaning of social entrepreneurship. 
http://fuqua.duke.edu/centre/case/document/dees_SE.pdf. accessed on september 20, 2013.

Di Domenico, M., Haugh, H. \& Tracy, P. (2010). Social bricolage: theorizing social value Creation. Social Entrepreneurship Theory and Practice, 34(4), 681-703.

Felicio, J.A., Goncalves, H.M. \& Goncalves, V.C. (2013). Social value and organizational performance in non-profit social organizations: social entrepreneurship, leadership and socio economic context effects. Journal of Business Research, 66, 2139-2146.

Frederickson, H.G. (1982). The recovery of civisms in public administration. Public Administration Review, 42(6), 501-508.

George, A.M. (2009). Identifying social entrepreneurs serving the poor at the BoP. William Davidson Institute Working Paper, 972.

Herman, R. \& Redina, D. (2001). Donor reaction to commercial activities of nonprofit organization: an American case study. International Journal of Voluntary and Nonprofit Organization, 12(2), 157-169.

Horgan, M.D. (2013). Social entrepreneurship: the ideal business for humanity and the economy.

Pomana Senior Thesis.Paper 78.http://scholarship.claremont.edu/pomana_theses/79. accessed August 20, 2013.

Jain, T.K. (2009). Discovering social entrepreneurship. Asian-Pacific Business Review. 5(1), 2234.

Kato, M.P. \& Mushi, L.D. (2012). Social entrepreneurship: how social entrepreneurs pioneering social change- the evidence from Tanzania. Journal of Economics and Sustainable Development, 3(10), 143-150.

Kerlin, J. (2009). Social entrepreneur a global comparism. $1^{\text {st }}$ ed. Lebanon Tufts University Press, 1-128.

Koresec, R.L. \& Berman, E.M. (2006). Municipal support for social entrepreneurship. Public Administrative Review, May/June, 448-461.

Kuratko, D. \& Hodgetts, R. (1998). Entrepreneurship: a contemporary approach. $4^{\text {th }}$ ed. Fort Worth, TX: Dryden Press.

Lewis, E. (1980). Public entrepreneurship: toward creative power. Bloomimgton: Indian University Press.

Light, P.C. (2006). Reshaping social entrepreneurship. Standford Social Innovation Review, (fall), 46-51. 
Luke, J. (1998). Catalytic leadership: strategies for an interconnected world. San Frascisco, Jossey-Bass.

Mair, J., Robertson, J. \&Hockerts, K. (2006). Social entrepreneurship. Eds. London, Palmgrave.

Mair, J. \& Martin, I. (2006). Social entrepreneurship research: a source of explanation, prediction and delight. Journal of World Business, 41(1), 36-44.

Marquez, N. (2008). Social entrepreneurship: a for profit approach to filling the gap in international environmental policy. Bologna Centre Journal of International Affairs, 14, 107-116.

Miller, T.L. \& Wesley, 11, C.L. (2010). Assessing mission and resources for social change: an organizational identity perspective on social venture capitalist decision criteria. Entrepreneurship Theory and Practice, 34(4), 705-733.

Moss, T.W., Lumpkin, G.T. \& Short, J.C. (2008). The dependent variable of social entrepreneurship research. Frontier of Entrepreneurship Research, 28(21).

Nanda, M.D. (2013). Social entrepreneurship and social work: the need for a transdisciplinary education model. Administration in Social Science, 37, 257-271.

Robinson, J.A., Mair, J. \&Hockertson, K. (2009). International perspectives of social entrepreneurship. Palgrave, London.

Rose, K. (1992). Where women are leaders: the SEWA movement in India. London: Zed book Ltd.

Roper, J. \& Cheney, G. (2005). Leadership, learning and human resources management: the meaning of social entrepreneurship today. Corporate Governance, 5(3), 95-104.

Savas, E. (1987). Privatization: the key to better government. Chalthan, NJ: ChalthanHouse.

Seelos C. \& Mair, J. (2013). How social entrepreneurs enable human social and economic development. Forth coming chapter in alleviating global poverty, Edited by Harvard Business School, Jossey bass.

Simha, A. \& Carey, M.R. (2012). The encyclical letter (Caristasinveritate)- a shout-out to school entrepreneurship? Journal of Entrepreneurship, 21(1), 1-23.

Thompson, J. (2002). The world of the social entrepreneur. Inter-Journal of Public Sector Management, 15(5), 412-431.

Thompson, J.L., Alvy, G. \& Lees, A. (2000). Social entrepreneurship: a new look at the people 
and their potential. Management Decision, 38(5), 328-338.

Ventresca, M.J. \& Dorado, S. (2013). Crescive entrepreneurship in complex social problems:

Institutional conditions for entrepreneurial engagement. Journal of Business Venturing, 28, 6-12.

Weerawardena, J. \& Mort, G.S. (2006). Investigating social entrepreneurship: a multi dimensional model. Journal of World Business, 4(1), 21-35.

Young, M. (1997). Do-gooders with savvy. New Statement, 126(1), 20-25.

Yusuf, M.B., Ibrahim, I.A. \& Hamid, M.B. (2013). Who is a social entrepreneur? Easy question difficult answer. $4^{\text {th }}$ International Conference on Business and Economic Research, $4^{\text {th }}$ March, Indonesia. 